\title{
ABHD12 wt Allele
}

National Cancer Institute

\section{Source}

National Cancer Institute. ABHD12 wt Allele. NCI Thesaurus. Code C118546.

Human ABHD12 wild-type allele is located in the vicinity of 20p11.21 and is approximately $96 \mathrm{~kb}$ in leng th. This allele, which encodes monoacylglycerol lipase ABHD12 protein, is involved in endocannabinoid catabolism. Mutation of the gene is associated with the neurological disorder, polyneuropathy, hearing loss, ataxia, retinitis pigmentosa, and cataract. 